\title{
ADVERSARIAL PRINCIPLE UNDER THE NEW CIVIL PROCEDURE IN UKRAINE
}

\author{
Volodymyr Kroitor, \\ PhD in Law, Professor at the Department of Civil Law \\ and Process, Kharkiv National University of Internal Affairs, \\ Ukraine \\ Valeriy Mamnitskyi, \\ PhD in Law, Associate Professor at the Civil Process \\ Department, Yaroslav the Wise National Law University, \\ Ukraine
}

doi.org/10.33327/AJEE-18-2.4-a000021

\begin{abstract}
Summary: - 1. Introduction. - 2. The Adversarial Principle of Civil Justice in Ukraine: Traditional Concepts of Implementation. - 2.1. Post-Socialist Trends in the Reform of Civil Procedural Legislation. - 2.2. The Right to a Fair Trial and the Competitiveness of Civil Proceedings. - 3. Balance of Adversarial Principles and Cooperation between Parties and Court in the Process of Civil Cases Consideration: a New View from Ukraine. - 3.1. Exchange of Pleadings and a New Procedure for Submitting Evidence in a Case. - 3.2. Prevention of Abuse of Procedural Rights during the Implementation of Adversarial Principle. - 4. Conclusions.
\end{abstract}

This work deals with the evolution of adversarial principle in civil process under the conditions of post-socialist regression and post-reform civil justice as well as the introduction of the principles of case management and cooperation between the court and the parties in the process. In particular, it analyses the main provisions of such new guarantees of realization of the right to a fair trial, which were introduced in the CPC of Ukraine in 2017-2018 as a court's right to prevent abuse of procedural rights, as well as the exchange of competitive documents between the parties. The authors argue that effective protection of the rights today is to be based on the adversarial principles that shall be supplemented by the security of the balance of rights of the parties and the authority of the court on the examination of civil matters.

Keywords: adversariality, equality of parties, principles of the civil procedure, competitiveness, procedural activity of the court, principle of cooperation between the parties and the judge 


\section{INTRODUCTION}

At the current stage of formation of a rule-of-law state in Ukraine, the aspiration of society for high standards of administration of justice and ensuring a real basis for the adaptation of the EU law require the conduct of scientific research on the conformity of national legislation and the European standards. In particular, there is a need to improve the rules of the judiciary, which provide real effective protection of the rights of those who appeal to the court.

The improvement of procedures for the administration of civil justice was first determined by the fact that on 17 July 1997, ${ }^{1}$ Ukraine ratified the Convention for the Protection of Human Rights and Fundamental Freedoms of 4 November 1950 (hereinafter referred to as the Convention). The fact of such ratification imposed the obligation on Ukraine to comply with those requirements for the protection of human rights defined by the European community, and, above all, the requirements regarding the accessibility of justice and human rights to a fair trial.

The signing of the Association Agreement between Ukraine and the EU in 2014 and the introduction of a comprehensive and deep free trade area has become a prerequisite for deepening and spreading economic and other social relations between the Union and our country. Subsequently, this has led to the need for further approximation of rules and approaches to the administration of justice, especially in civil cases.

The changes that have taken place in Ukraine over the past few years indicate a move towards further restructuring and approximation of legislation to the EU law, in particular in the area of civil process. Revision and rethinking the role of the court in the process of reviewing and resolving civil cases has become one of the evolutionary steps in this direction. At the same time, this calls for a comprehensive balanced scientific understanding of the concerted action of all institutes of civil procedural law. In particular, it concerns the balance of interests of the parties and new guarantees of the implementation of the adversarial principle in the process, which has been repeatedly subjected to evolutionary changes. The adversarial principle is one of the fundamental principles of civil justice, which has traditionally been considered an immanent feature of the administration of justice and the search for truth in a dispute. In order to improve the existing model of domestic civil justice in Ukraine, the purpose of this study is to justify the need to introduce a more balanced approach to the implementation of the adversarial principle in civil justice and optimize the procedure for judicial review of cases in order to improve the efficiency of the administration of justice and create a coherent justice system in accordance with European standards of justice.

1 The law of Ukraine 'On Ratification of the Convention for the Protection of Human Rights and Fundamental Freedoms’ of 1950, The First Protocol and Protocols № 2, 4, 7 and 11 to the Convention of 17 July 1997 (1997) 40 Bulletin of the Verkhovna Rada of Ukraine 263. 


\section{THE ADVERSARIAL PRINCIPLE OF CIVIL JUSTICE IN UKRAINE: TRADITIONAL CONCEPTS OF IMPLEMENTATION}

\subsection{Post-Socialist Trends in the Reform of Civil Procedural Legislation}

At a time when Ukraine was a part of the Soviet Union, the dominant basis of civil justice was the adversarial principle with substantive investigative basis, which, at times, hindered the adversarial principle itself. According to Art. 30 of the Civil Procedural Code of the Ukrainian SSR in 1963 (hereinafter referred to as the CPC of 1963), ${ }^{2}$ each party shall prove the circumstances to which it refers as a basis for its claims and objections. However, in other articles of the CPC of 1963 it was also recognized that the court shall, without limiting to the material provided and the parties' explanations, use all the measures envisaged by law to comprehensively, fully and objectively clarify the actual circumstances of the case, the rights and responsibilities of the parties (part one of Article 15 of the CPC of 1963); if the evidence provided was insufficient, the court offered the parties and other persons involved in the case to submit additional evidence or gather them on their own initiative; the court was obliged to assess the evidence on the basis of a comprehensive, complete and objective consideration of all the circumstances of the case (Article 62), that is, not only submitted by the parties, but also all those that the court had to gather itself.

According to the analysis of these articles of the CPC of Ukraine, the content of the adversarial principle was in fact neutralized by the active role of the court in clarifying the circumstances of the case and consolidation of the principle of objective truth. As a result, the burden of gathering evidence was assigned to the court, while the parties could restrain from any actions without liability. It is necessary to note that this position was in line with the social, economic and political principles of society that existed at that time. Accordingly, in Soviet law, with the domination of a politicized thought that the contradiction between the interests of the individual and the state is unthinkable, the competition of the parties in the court was considered not as a confrontation, but as a martial art in the name of achieving objective truth, and therefore the principle was filled with a completely different ideological meaning.

Significant evolutionary changes regarding the content of the adversarial principle have taken place during the time of Ukraine's independence. On 2 February 1996, the Law of Ukraine 'On Amendments and Additions to the Civil Procedural Code of Ukraine' created an almost 'perfect' adversarial model of civil justice, which was based almost on a 'pure' competition without any investigative principles. The court's initiative to collect evidence was minimized, and the only case of court intervention in managing evidence was the right and duty of the court to appoint forensic psychiatric examination on cases of recognition of a citizen as incapacitated (Article 255 of the CPC of Ukraine).

2 The Civil Procedural Code of the Ukrainian SSR: The Law of Ukraine of 18 July 1963 (1963) 30 Bulletin of the Verkhovna Rada of the USSR 464. 
In 2004 the Verkhovna Rada of Ukraine, conducting judicial reform, adopted a new CPC of Ukraine, ${ }^{3}$ in which the content of the adversarial principle acquired new features, which were not inherent to it earlier. The legislator generally took into account the proposals of processualists and practitioners on the need to change the role of the court in the process of collecting evidence in the new CPC of Ukraine. According to Article 10 of the CPC of Ukraine (as of 2005, at the moment of its entry into force), civil proceedings are conducted on the basis of the parties' adversarial procedure, and the parties and other persons involved in the case have equal rights to submit evidence, to investigate and prove them before the court. Accordingly, each party is obliged to prove the circumstances to which it refers to as a basis for its claims or objections, except cases established by the CPC of Ukraine. The court, in accordance with the provisions of the new CPC, should contribute to a comprehensive and complete clarification of the circumstances of the case: to explain to the persons involved in the case their rights and duties, to warn about the consequences of committing or not proceeding with procedural actions and to promote the exercise of their rights in cases, established by law.

The desire to reorganize and achieve effective protection of parties in contrast to the model of active court in the process of post-socialist civil proceedings has led to such changes in the provisions of the $\mathrm{CPC}$, which resulted in an almost complete neutralization of the role of the court in the course of consideration of the case. While managing the course of the trial and consideration of the case, the judge did not have the powers and instruments of effective influence on the parties' behaviour, which became a reliable ground for the development of a systematic abuse of procedural rights, and eventually to a significant reduction in the level of trust in the judiciary.

Such an imbalance of rights of the parties and the powers of the court in the process did not ensure the timely consideration of cases by the court: over the decades, Ukraine has been leading in the number of appeals to the ECHR for violation of the right to fair judicial protection within a reasonable time. Thus, such a system required changes.

In the light of recent legislative reforms in the justice system, the traditional approaches and approaches introduced in the CPC of 2004 have been substantially revised. In the CPC of Ukraine of $2017^{4}$ the adversarial principle has acquired such new features that were not inherent to it earlier, which will be analysed in detail in the subsequent sections.

\subsection{The Right to a Fair Trial and the Competitiveness of Civil Proceedings}

Modern democratic reforms in Ukraine directly affect the necessity of further formation and development of the national judicial system, increase of efficiency of administration of justice, updating of procedural legislation and creation of a system of legal proceedings in accordance with the European standards of justice. In drafting the current CPC of Ukraine of 2004, including the provisions relating to the basic principles of the civil

3 The Civil Procedural Code of Ukraine: The Law of Ukraine of 18 March, 2004 (2004) 16 Official Bulletin of Ukraine 1088.

4 The Law of Ukraine of 03.10.2017 'On the Amendments to the Commercial Procedural Code of Ukraine, Civil Procedural Code of Ukraine, Code of Administrative Justice of Ukraine and other Legislative Acts' (2017)221-222 Holos Ukrainy. 
process, the fundamental postulates embodied in the international legal acts ratified by Ukraine were taken into account.

In particular, the CPC of Ukraine is based on the consolidation of the principles of the civil process in accordance with Art. 8 of the Universal Declaration of Human Rights of 10 December 1948, which enshrines the right of every person to effectively restore rights in the competent national courts in cases of violation of his/her basic rights granted to him/her by the Constitution and the law. ${ }^{5}$ In addition, the CPC of Ukraine reflects the basic provisions of the Convention for the Protection of Human Rights and Fundamental Freedoms and its Protocols, which became a part of national legislation as a result of their ratification by Ukraine on 17 July 1997, ${ }^{6}$ as well as Art. 55 of the Constitution of Ukraine, ${ }^{7}$ which proclaimed the protection of the rights and freedoms of a person and a citizen by a court.

Article 6 of the Convention establishes the right to a fair trial. However, the right of access to justice, as well as the right to a fair trial, which are enshrined in the convention, are abstract, and they are personified only in a concrete process and in relation to a certain circle of subjects of procedural activity, which are, first and foremost, the parties and other interested persons. Accordingly, we consider that one of the main components and substantive elements of the right to a fair trial, which is inherent to the interested parties of procedural activities, is the due process of law, which, in our opinion, is the result of the construction of a certain model of civil justice at the legislative level.

In its decisions, the ECHR often refers to the analysis of the essence of the adversarial principles, the equality of parties in the process, as well as the study of the balance of rights of the parties and the powers of the court in the process. Thus, in the case of Vermulen versus Belgium, the European Court of Human Rights found the violation of part 1 of Article 6 of the Convention, that is, the right to a fair trial, that the applicant could not, through the assistance of his lawyer, respond to the statement made by the Deputy General Prosecutor at the Court of Cassation, as well as to apply to the court himself during the hearings in the Court of Cassation. The court noted that the adversarial principle means that the parties in the criminal or civil process have the right to get acquainted with all the evidence or remarks made in the case and to comment on them; this also applies to the findings made by the independent representatives of the prosecutor's office, which influence the decision of the court. ${ }^{8}$ In the case of Kostovskyi versus The Netherlands, the European Court emphasized that, in accordance with the principle of adversarial proceedings, all evidence should be presented in the presence of the accused at an open hearing. As a rule, these rights require the accused to have equal and proper opportunity to refute the testimony of the witness and his interrogation. ${ }^{9}$ In the case of Krtsmar versus The Czech Republic, it was stated that in the course of the adversarial process, any party

$5 \quad$ The Universal Declaration of Human Rights of 10 December 1948 <http://zakon5.rada.gov.ua/laws/ show/995_015 > accessed 8 December 2019.

6 Convention for the Protection of Human Rights and Fundamental Freedoms of 04.11.1950 < http:// zakon0.rada.gov.ua/laws/show/995_004 > accessed 8 December 2019.

7 The Constitution of Ukraine : adopted at the fifth session of the Verkhovna Rada of Ukraine on 28.06.1996 (1996) 30 Bulletin of the Verkhovna Rada of Ukraine 141.

8 The European Court of Human Rights: Selected decisions, vol 1 ( Norma 2000) 175-177.

9 The European Court of Human Rights Practice. Decisions. Commentaries (2002) №1 203. 
to the proceedings should have the opportunity to review the evidence before the court, and to have the opportunity to express their opinion on their availability, content and authenticity in the appropriate form and at the appropriate time, and if necessary - in writing and in advance. ${ }^{10}$ Based on the case law of the European Court of Human Rights, it is logical to conclude that the adversarial principle, balanced by the principles of equality of parties in the process, is integral to the right to a fair trial.

For the Strasbourg judges, procedural equality prevails over adversariality, which is a means of achieving parity of opportunities and knowledge of the parties in regards to evidence in civil proceedings. ${ }^{11}$ The proof of this is the ruling of 28 August 1991 in the case of Brandstattter versus Austria, some provisions of which read as follows: 'The right to an adversarial proceeding means that ... should be given the opportunity to review and comment on the observations submitted and the evidence put forward by the other party. National legislation can enforce this requirement in a variety of ways. However, regardless of the method chosen, it shall ensure that the other party is informed about the comments provided and has a real opportunity to state their opinion about them. ${ }^{12}$

The ECHR approaches to the implementation of the adversarial principle are aimed at securing the right of a person to a fair trial. But over the time elapsed since the ratification of the Convention by Ukraine, it has become clear that such a concept of the national civil process is not entirely consistent with the realities and practices of the ECHR, which has become an important ground for modern reform.

\section{BALANCE OF ADVERSARIAL PRINCIPLES AND COOPERATION BETWEEN PARTIES AND COURT IN THE PROCESS OF CIVIL CASES CONSIDERATION: A NEW VIEW FROM UKRAINE}

\subsection{Exchange of Pleadings and a New Procedure for Submitting Evidence in a Case}

The reform of civil justice in Ukraine during 2014-2018 began with changes to the Constitution of Ukraine, which consolidated the right of everyone to professional legal assistance, and also changed the approach to judicial jurisdiction. Under the new provisions, the precondition for applying to the court for the protection of rights is the application of the extrajudicial ways of resolving disputes provided by law.

Accordingly, the general principles of civil justice have also undergone changes. General provisions on the implementation of the adversarial principle are reflected in Part 1 of Art. 12 of the CPC of Ukraine. Thus, it is assumed that the parties to the case have equal rights to exercise all procedural rights and obligations provided for by law, and each party shall prove circumstances relevant to the case and which it refers to as grounds for their claims or objections, except in cases, established by this Code.

10 The European Court of Human Rights Practice. Decisions. Commentaries (n 79) 35-36.

11 D Homien, D Harris, L Zvaak, The European Convention on Human Rights and the European Social Charter (Moscow 1998) 221.

12 Case of Brandstetter $v$ Austria <http://hudoc.echr.coe.int/eng?i=001-57683 http://echr.coe.int/echr > accessed 8 December 2019 
But the new civil procedural law puts certain limits on the parties to the case in regards to adversarial trial realization. Thus, in Part 4 of Art. 12 of the CPC it is stipulated that each party bears the risk of consequences arising from the commission or nonexecution of procedural actions. This norm is actually blank and disclosed in the special rules of the CPC of Ukraine. This is a special procedure for the exchange of pleadings, which did not exist before the reform of the CPC, as well as the powers of the court to prevent the abuse of procedural rights, which is also a novelty for Ukraine.

In particular, according to Art. 175 of the CPC of Ukraine, a statement of claim shall be submitted to the court in writing and signed by the plaintiff or his representative, or another person whom the law granted the right to apply to the court in the interests of another person.

The statement of claim shall contain a list of documents and other evidence attached to the application; indication of evidence that cannot be filed together with the statement of claim (if any); indication as to whether the plaintiff or other person has the original written or electronic evidence, copies of which are attached to the application. That is, the evidence shall be indicated by the plaintiff immediately upon presentation of the statement of claim.

After the opening of the proceedings and receipt of the defendant's statement of claim, the latter has the right to exercise his/her right of revocation to the statement of claim. According to Art. 178 of the CPC of Ukraine, in the revocation of the defendant, he/she sets out the objections to the claim, as well as a list of documents and other evidence, and the indication of documents and evidence that cannot be filed together with the revocation, with the reasons for not filing them.

In addition, in accordance with Part 5 of Art. 178 of the CPC of Ukraine evidence confirming the circumstances on which the defendant's objections are based are added to revocation if such evidence is not provided by the plaintiff; as well as documents confirming the sending (giving) of the revocation and the evidence attached to it by other participants of the case.

The legislator provided that the revocation should be filed in due time, established by a court, which should not be less than fifteen days from the date of the order to open the proceedings. The court was also empowered to set such time-limits for filing a revocation, which would enable the defendant to prepare the revocation and the relevant evidence, and enable other parties to the case to receive a revocation no later than the first preparatory meeting in the case. In case of failure to provide the defendant with a revocation within the time limit established by the court without good reason, the court shall settle the case on the available materials. A defendant who failed to provide the court with evidence against the stated claims is unable to refer to such evidence in future.

Similarly, according to Art. 83 of the CPC of Ukraine, the defendant, a third person who does not declare independent claims regarding the subject of the dispute, shall file evidence to the court together with the filing of the statement or written explanations of the third person.

If the evidence cannot be filed in the designated term for objective reasons, the party to the case shall notify the court in writing and indicate: the evidence which cannot 
be filed; the reasons why evidence cannot be filed within the specified time period; evidence that the person has made all the possible actions to obtain the said evidence.

In the event of the recognition of valid reasons for failure by the party to submit evidence in the designated term, the court may impose an additional time limit for the submission of the said evidence. However, evidence that is not filed within the term designated by law or court is not admitted, except when the person submitting them substantiates the impossibility of submitting them within the specified time for reasons that were not under his/her control.

At the same time, the question of the sufficiency of evidence to establish circumstances relevant to the case is attributed to the powers of court. It decides the question in accordance with its internal conviction. Accordingly, a balance is struck between the rights of parties and the powers of court, which ensures the implementation of the principle of their cooperation in order to review the case.

This is confirmed by the following example of judicial practice. Thus, in a ruling of the Supreme Court of 4 October 2018 in the case No. 686/24319/16-ц in the lawsuit of PERSON_1 to Malynitske village council of the Khmelnytskyi raion of Khmelnytskyi oblast, PERSON_5 on invalidation and cancellation of the decisions of village council session, invalidation of the state act on the right of property to a land lot, the court notes the following. Paragraph 1 of the first part of Article 60 of the CPC of Ukraine (as amended at the time of the decision of the court of first instance) stipulates that each party is required to prove the circumstances to which it refers as a basis for its claims and objections (part one of Article 81 of CPC of Ukraine of 2017).

Having established that the granting PERSON_5 the right of property to a land lot did not violate the rights of PERSON_4, and the plaintiff was not provided with proper and admissible evidence that the disputed land was transferred to him free of charge into private property, the court of first instance, which conclusion was agreed by the court of appeal, made a reasonable conclusion of the refusal to satisfy the claim.

The ECHR indicated that, in accordance with its common practice, which reflects the principle of proper administration of justice, the decisions of courts and other bodies of disputes resolution should adequately state the grounds upon which they are based. Although item 1 of Article 6 of the Convention obliges courts to justify their decisions, it cannot be construed as requiring a detailed answer to every argument. The measure to which the court shall fulfil the obligation to substantiate the decision may vary, depending on the nature of the decision (Seriavin et al. versus Ukraine, No. 4909/04, $₫$ 58, ECHR, of 10 February 2010).

The following example of judicial practice reflects the procedure for the submission and examination of the originals of evidence referred to by the parties to the case. The Supreme Court in the ruling of 10 October 2018 in the case No.442/3989/17 on the claim of PERSON_1 to PERSON_5, the third person - PERSON_6, on the collection of alimony payment for maintenance of an adult son who is continuing education notes that the evidence provided by the defendant is not properly certified, is erroneous in the light of the following.

According to part one of Article 76 of the CPC of Ukraine, evidence is any data on the basis of which the court establishes the presence or absence of circumstances 
(facts) justifying the claims and objections of the participants in the case, and other circumstances that are relevant for the resolution of the case.

Parts one, two, five, and six of Article 95 of the CPC of Ukraine stipulate that written documents are documents (other than electronic documents) containing information about the circumstances relevant to the proper resolution of the dispute. Written evidence is filed in the original or in a duly certified copy, unless otherwise provided by this Code. A participant to the case, who submits written evidence in copies (electronic copies), shall indicate that he/she or another person has the original written evidence. The participant to the case shall confirm the correspondence of a copy of the written evidence to the original which he/she has, with his/her signature indicating the date of such certification. If a copy (electronic copy) of written evidence is filed, the court may, at the request of the participant in the case or on its own initiative, request the original written evidence from the person concerned. If the original of the written evidence is not filed, and the participant or the court questions the conformity of the submitted copy (electronic copy) with the original, such evidence is not taken into account by the court.

From the technical record of the Court of Appeal hearing, which took place on 19 December 2017, it was established that the court of appellate instance investigated the originals of the evidence submitted by the defendant to confirm the circumstances set out in the appeal.

Other arguments of the cassation appeal are disproved by the circumstances of the case established by the appellate court and are essentially reduced to disagreement with the court's findings regarding the establishment of these circumstances, contain references to the facts that were the subject of study and assessment by the court, which it justifiably denied.

The ECHR pointed out that the first paragraph of Article 6 of the Convention obliges courts to justify their decisions, but this cannot be taken as a requirement to provide a detailed answer to every argument. The boundaries of this duty may vary, depending on the nature of the decision. In addition, it is necessary to take into account, among other things, the variety of arguments that the party can submit to the court and the differences existing in the participating States, taking into account the provisions of the law, traditions, legal conclusions, statement and formulation of decisions. Thus, the question whether the court fulfilled its obligation to submit a substantiation arising from Article 6 of the Convention can be determined only in the light of the specific circumstances of the case (paragraph 23 of the ECHR ruling of 18 July 2006 in the case of Pronin versus Ukraine).

Consequently, procedural law establishes not only the timeframe for the submission of evidence, but also the procedure of submitting evidence, which shall be sent to other participants in the case. If the parties to the proceedings fail to comply with such conditions for the submission of evidence, the court will not take them into consideration and consider the case only on the materials available.

\subsection{Prevention of Abuse of Procedural Rights during the Implementation of Adversarial Principle}

In accordance with these provisions of the current CPC of Ukraine of 2017, during the implementation of adversarial principle in civil justice, the court now plays a 
decisive role. According to Part 5 of Art. 12 of the CPC of Ukraine, the court, while maintaining objectivity and impartiality, controls the course of the trial; facilitates settlement of a dispute by reaching an agreement between the parties; clarifies, in case of necessity, the procedural rights and obligations of the participants in the judicial process, the consequences of committing or not committing procedural actions; encourages participants in the judicial process to exercise their rights provided for in this Code; prevents the abuse of rights of the participants in the judicial process and takes steps to fulfil their duties. It received such a set of powers that allows it to guarantee the right of a person to a fair trial more effectively.

In particular, the clarification of the court procedural rights and obligations of the participants in the process is crucial for ensuring effective legal proceedings. Thus, $\mathrm{L}$. Rosenberg and K. Schwab consider that in the civil process the adversarial principle is not an immutable dogma, but, on the contrary, in the interests of the efficiency of legal proceedings, judicial assistance for the clarification of the circumstances of the case is necessary. ${ }^{13}$ The authors argue that the adversarial principle places the burden of proof on the parties, and in connection to this it is impossible to ignore the significant role of the court, which is to assist the parties in providing relevant evidence. Such promotion of the court (procedural activity of the court) is carried out through the obligation of the judge to provide the relevant explanations (richterliche Aufklarungspflicht). It is important to note that the duty of the judge to clarify, its promotion is the need of a social and legal state and an important means of replenishing evidence.

But along with this, the court should provide tools to prevent the abuse of procedural rights, without which clarification of the rights of participants becomes an illusory fiction, which is not implemented during the consideration of the case. Thus, for the first time in Ukraine's independence, the court received the right to apply measures to influence the unfair behaviour of the participants in the case.

Article 148 of the CPC of Ukraine provides for the application of a fine to the participants in the case for failure to comply with the legal requirements of the court, including the failure to comply with the decision to require evidence. Thus, the said norm stipulates that the court may order a decision on the collection a fine in the amount of 0,3 to 3 times the subsistence minimum for able-bodied individuals to the state budget from the person concerned in the following cases:

1) failure to perform procedural duties, in particular, evasion from the commission of actions imposed by a court on a participant in a judicial process;

2) abuse of procedural rights, commission of acts or assumption of inactivity in order to interfere with legal proceedings;

3) failure to inform the court of the impossibility of submitting evidence demanded by the court, or failure to submit such evidence without good reason;

4) failure to comply with the decision on the securing of claim or evidence, failure to provide a copy of the revocation for review, appeal or cassation appeal, the response

13 L Rosenberg, K Schwab, Zivilprozessrecht, 15 Aufl (Beck 1993) 425. 
to the revocation, the objection to another party to the case within the time limit prescribed by the court.

In the event of repeated or systematic non-compliance with procedural obligations, repeated or systematic abuse of procedural rights, repeated or systematic failure to submit evidence sought by the court without good reason or without notification, the failure to secure the claim or evidence, the court, taking into account specific circumstances, collects a fine in the amount of one to ten times the subsistence minimum for ablebodied individuals to the state budget from the relevant participant in the trial or another person concerned.

In case of non-fulfilment of procedural obligations, abuse of procedural rights by a representative of a participant in a case, the court may, after taking into account the particular circumstances of the case, collect a fine from both the participant in the case, and his/her representative.

The court also promotes the parties in requesting evidence, thus influencing the course of the case. According to Art. 84 of the CPC of Ukraine, a party to the case, in case of impossibility to provide evidence on its own, is entitled to file a petition requesting evidence by a court. Such a petition shall be filed within the term specified in parts two and three of Article 83 of this Code. If such a request is filed outside the specified term, the court leaves it without satisfaction, except when the person who submits it justifies that it was impossible to submit it in due time for reasons outside his/her control.

Any person who holds evidence shall submit it to the court on request. Persons who are not in a position to file evidence, which the court requests, or are not able to submit such evidence within the established time limits, are required to inform the court of the reasons within five days from the date of delivery of the ruling.

In case of failure to inform the court of the impossibility to submit the evidence requested by the court, as well as of failure to submit such evidence for reasons recognized by the court as not important, the court applies to the person concerned the measures of procedural coercion provided for in this Code.

The prosecution of guilty persons does not relieve them of the obligation to file evidence requested by the court.

In case of failure by the participant in the case to submit the evidence requested by the court for disreputable reasons or without notification about the reasons for not submitting the evidence, the court may, depending on the person who avoids the submission, and also the significance of these evidence, recognize the circumstance for which the evidence was sought, or refuse to recognize it, or may consider the case on the evidence available at the time, or, in case the plaintiff fails to submit such evidence, also leave the claim without consideration.

Thus, summing up the foregoing, one may come to the conclusion that the violation by the participants in a civil case of the order for submission of evidence, the timing of submission of evidence, or failure to comply with a court order regarding the reclamation of evidence may lead to negative consequences for them: the consideration of the case on the merits, which in the future can lead to a refusal to satisfy a claim or to leave a claim without consideration. 


\section{CONCLUSIONS}

Judicial reform has unquestionably changed the function of the court in the trial. Now the law is based on the provision that civil judicial proceedings are carried out on the adversarial basis, but with the active assistance of the court, that is, on the terms of their cooperation, in order to effectively deal with the case.

At the same time, the economic conditions of the activity of the bar and the notary, which, above all, provide the opportunity for citizens to receive qualified legal aid, have changed. It should be noted that in the present situation in the country a significant part of low-income population as a result of rather progressive changes to the CPC of Ukraine in 2017, face significant obstacles to the realization of their right to judicial protection. As practice shows, the system of legislation is so complicated that without a professional legal assistance from a lawyer or specialist in the field of law it is almost impossible to hear a civil case in court.

The adoption of appropriate new measures and the improvement of existing procedures aimed at a more efficient administration of justice should be taken in the complex and certainly not worsen the situation of citizens regarding the possibilities for citizens to exercise their right to judicial protection.

The problem of access to justice in the conditions of effect of the adversarial principle can certainly not be limited to the possibility of providing free legal aid of lawyers and appropriate compensation by the state. A number of public institutions need to be developed that will help protect the rights of the poor and those who find themselves in a difficult situation because of their health or age.

The rights of the parties and the powers of the court, enshrined in the law, according to our conviction, aim at maintaining the balance between the parties' adversarial power in their attempt to prove their correctness and the activity of the court, which ensures effective consideration and resolution of the case. Such a balance should penetrate the entire CPC of Ukraine: the rules on the procedural activity of the parties (and other persons involved in the case) and the courts interact with and complement each other. This is the right way to realize the main task of civil justice and to achieve a fair, impartial and timely consideration and resolution of civil cases with the aim of effectively protecting violated, unrecognized or challenged rights, freedoms or interests. The active powers of the court should be considered only as a guarantee of realization of the right to a fair trial and ensuring the balance of public-law and private-law interests. 